УДК 577.2

DOI: $10.33184 /$ spbgb-2021-09-21.28

\title{
Влияние 24-эпибрассинолида на водный обмен растений пшеницы при дефиците воды
}

\author{
(С А.Р. Лубянова, М.В. Безрукова, Ф.М. Шакирова \\ Институт биохимии и генетики - обособленное структурное подразделение \\ Федерального государственного бюджетного научного учреждения Уфримского \\ фредерального исследовательского центра Российской академии наук \\ Россия, Уфра, 450054,Октября, 71, лит 1е
}

\section{Email:Lubyanova555@mail.ru}

Исследовали влияние предпосевной обработки семян пшеницы (Triticum aestivum L.) сорта Салават Юлаев 0.4 мкМ 24-эпибрассинолидом (ЭБ) на показатели водного обмена проростков в нормальных условиях и при обезвоживании, создаваемом $12 \%$ полиэтиленгликолем (ПЭГ). Выявлено, что предобработка ЭБ снижала потерю воды при действии $12 \%$ ПЭГ. Уменьшение стресс-индуцированной потери воды растениями происходило за счет регуляции процессов транспирации и накопления осмотически активных веществ.

Ключевые слова: Triticum aestivum L., брассиностероиды, водный обмен, дефицит воды, оводненность, осмотический потенциал клеточного сока, относительное содержание воды, транспирация, 24-эпибрассинолид.

Среди абиотических стрессовых факторов, значительно снижающих урожайность сельскохозяйственных растений, часто наблюдается засуха. В стрессовых условиях окружающей среды растения, будучи прикрепленными к своему местообитанию, изменяют свои биохимические и физиологические процессы, направляя ресурсы на выживание. Характерными защитными реакциями растений при засухе, которые направлены на уменьшение потери воды растительным организмом, являются накопление осмотически активных веществ и закрытие устьиц. Значительное снижение транспирации и газообмена через устьица, в свою очередь, вызывает торможение фотосинтеза. При действии стрессовых фракторов растения стремятся сохранить баланс и избежать не только блокирования процессов фотосинтеза, но и предотвратить потерю воды. Главными регуляторами, координирующими стресс-индуцированные фризиологические и биохимические изменения, выступают фитогормоны, которые можно экзогенно применять для смягчения последствий воздействия стрессоров, в том числе и засухи, на метаболизм и рост растений. Хорошо известна ключевая роль АБК в реализации защитных механизмов в стрессовых условиях окружающей среды [1]. Наряду с этим активно исследуется участие брассиностероидов (БС) в реализации стресс-устойчивости растений $[1,2]$. Известно, что регуляция движения устьиц имеет решающее значение для адаптации многих видов растений к произрастанию в изменчивых погодных условиях и контролируется комбинированным действием АБК и БС [3]. В наших экспериментах мы оценивали способность БС индуцировать и сохранять устойчивость водного обмена растений пшеницы к дефициту воды.

Исследования проводились в лабораторных условиях на растениях пшеницы (Triticum aestivum L.) сорта Салават Юлаев. Семена замачивали в течение трех часов в растворе 0.4 мкM 24-эпибрассинолида (ЭБ). Контрольные семена замачивали в дистиллированной воде. Растения выращивали при 16-часовом фротопериоде и освещенности 270 
мКМ/( $\left.{ }^{2 *} \mathrm{c}\right)$ ФАР в течение 8 суток на 10\%-ной среде Хогланда-Арнона. В дальнейшем все проростки разделяли на две группы. Растения первой группы продолжали расти на 10\%-ном растворе Хогланда-Арнона (контроль и (ЭБ)), растения второй группы переносили на $12 \%$ полиэтиленгликоля (ПЭГ), растворенный в 10\%-ной среде ХогландаАрнона (ПЭГ и (ЭБ)+ПЭГ). Каждый вариант эксперимента содержал 3-5 повторов.

Транспирацию определяли, анализируя потерю массы стаканчика с проростками в питательном растворе, поделенную на время между измерениями и количество проростков [4]. Для предотвращения испарения жидкости с поверхности сосудов проростки закрывали алюминиевой фрольгой.

Оводненность корней определяли взвешиванием растительного материала сразу после отбора проб, сушки в открытых контейнерах, которые обеспечивают свободную циркуляцию воздуха, при температуре $70^{\circ} \mathrm{C}$. Повторное взвешивание проводили через 24 часа после достижения постоянного веса при двух последовательных взвешиваниях. Содержание воды рассчитывали по фрормуле: оводненность = [(сырая масса - сухая масса)/сырая масса] × 100\%.

Относительное содержание воды (ОСВ) в листьях рассчитывали по формуле: OCB=([сырая масса - сухая масса] / [масса при полном тургоре - сухая масса] $) \times 100 \%$. Сырую массу определяли сразу после отделения листьев от растения. Для определения тургорной массы листья помещали при комнатной температуре на 24 ч в темноту в закрытые сосуды, погружая основанием в дистиллированную воду [5]. После определения массы при полном тургоре листья высушивали и рассчитывали ОСВ.
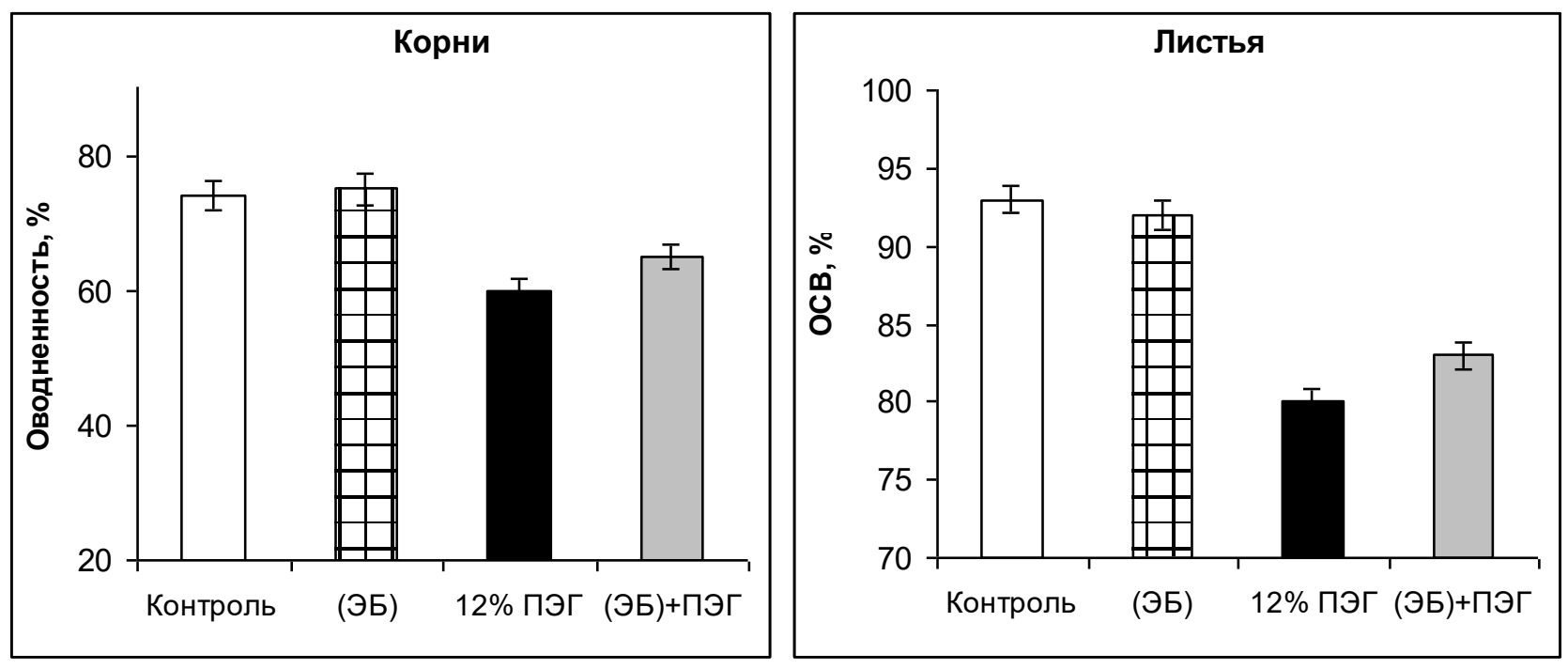

Рис. 1. Эфффект предобработки 0.4 мкМ ЭБ на оводненность корней и относительное содержание воды (ОСВ) в листьях пшеницы при воздействии $12 \%$ ПЭГ. (ЭБ) - предпосевная обработка семян 24-эпибрассинолидом; ПЭГ - выдерживание в течение 5 ч проростков пшеницы на растворе 12\% полиэтиленгликоля; (ЭБ)+ ПЭГ - предпосевная обработка семян 24-эпибрассинолидом с последующим выдерживанием 5 ч на 12\% полиэтиленгликоле. 
Осмотический стресс снижал оводненность корней на $14 \%$, тогда как листья оказались более защищены и показатель ОСВ после 5 ч воздействия 12\% ПЭГ снижался на $7 \%$ относительно контроля (рис. 1). В отсутствие стрессового воздействия предобработанные ЭБ проростки по показателям содержания воды в корнях и листьях не отличались от контрольных растений. В присутствии ПЭГ содержание воды предобработанных ЭБ листьев и корней растений пшеницы было на 3-5\% выше, чем у ЭБ-необработанных проростков.

Накопление осмотически активных веществ в растениях - характерная реакция стремящихся удержать воду растений в ответ на дефицит воды в окружающей среде. В наших экспериментах предпосевная обработка семян ЭБ не повлияла на накопление осмотически активных веществ проростков пшеницы в оптимальных условиях произрастания, однако после 24 ч воздействия 12\% ПЭГ наблюдалось уменьшение осмотического потенциала клеточного сока на $80 \%$ относительно контрольных растений (рис. 2). Показатель осмотического потенциала клеточного сока растений пшеницы, семена которых перед посевом предобработали ЭБ, был выше на 30\% на фоне стресса, чем у необработанных ЭБ стрессированных растений.
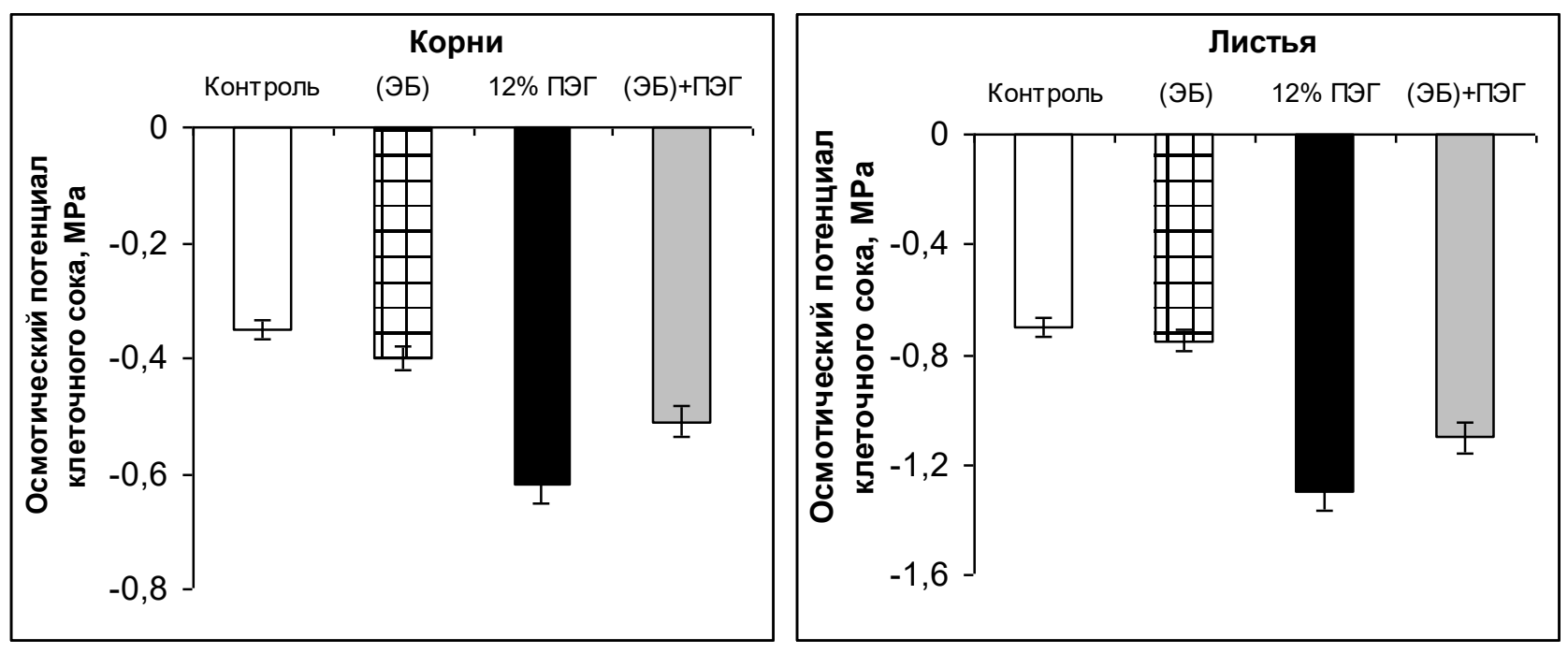

Рис. 2. Влияние предпосевной обработки семян 0.4 мкМ ЭБ на осмотический потенциал корней и листьев 9-суточных проростков пшеницы после воздействия $12 \%$ ПЭГ. (ЭБ) - предобработка 24-эпибрассинолидом; ПЭГ - выдерживание в течение 24 ч проростков пшеницы на растворе $12 \%$ полиэтиленгликоля; (ЭБ)+ ПЭГ - предпосевная обработка семян 24-эпибрассинолидом с последующим выдерживанием 24 ч на $12 \%$ полиэтиленгликоле.

Значимых отличий у листьев ЭБ-предобрабонанных проростков пшеницы от контрольных значений по уровню транспирации не было (рис. 3). Осмотический стресс, вызванный присутствием в среде Хогланда-Арнона $12 \%$ ПЭГ, приводил к резкому снижению уровня транспирационных потерь воды на 30\% по сравнению с контрольными растениями уже в первый час воздействия стрессора. К 5 часам воздействия обезвоживания наблюдалось двукратное сокращение транспирации. Предпосевная обработка ЭБ при последующем воздействии $12 \%$ ПЭГ на $20 \%$ увеличивала транспирацию листьев пшеницы по сравнению с только стрессированными растениями. 


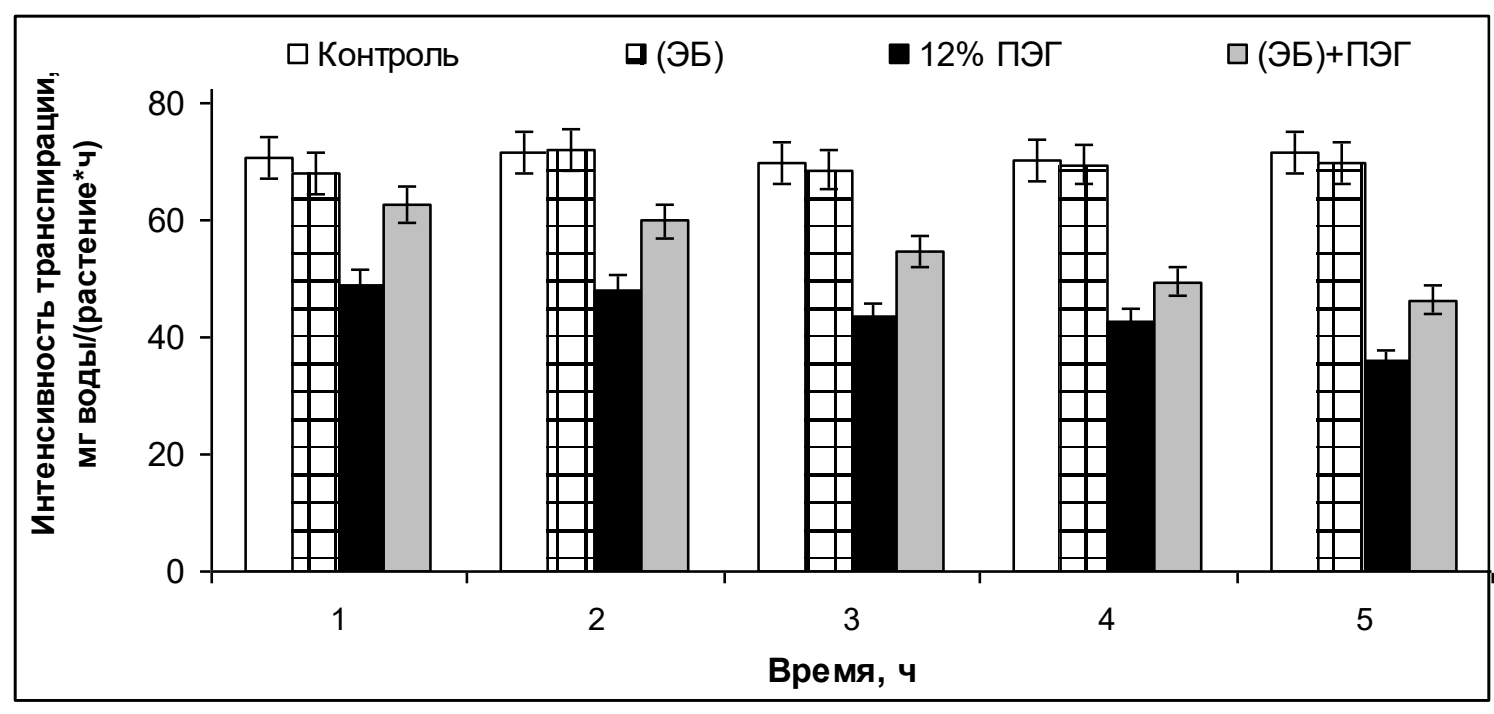

Рис. 3. Интенсивность транспирации растений пшеницы, выращенных из предобработанных и необработанных 0.4 мкМ ЭБ семян в условиях осмотического стресса. (ЭБ) предпосевная обработка 24-эпибрассинолидом; ПЭГ - выдерживание в течение 54 проростков пшеницы на растворе $12 \%$ полиэтиленгликоля; (ЭБ)+ПЭГ - предпосевная обработка семян 24-эпибрассинолидом с последующим выдерживанием 5 ч на 12\% полиэтиленгликоле.

Полученные данные свидетельствуют о том, что предпосевная обработка семян 0.4 мкМ 24-эпибрассинолидом оказывает защитный эфрфект, смягчая последующее влияние дефицита воды на водный обмен растений пшеницы, что отражается на таких показателях, как содержание воды и накопление осмотически активных веществ в проростках пшеницы, а также транспирации листьев.

Работа выполнена при поддержке гранта Российского фонда фундаментальных исследований (20-04-00904a) и частично в рамках госзадания (№ гос. регистрации AАAА-A16-116020350029-1) с привлечением приборного парка ЦКП «Биомика» (Отделение биохимических методов исследований и нанобиотехнологии РЦКП «Агидель») и УНУ «КОДИНК».

\section{Литература}

1. Eyidogan F., Oz M.T., Yucel M., Oktem H.A. Signal Transduction of Phytohormones Under Abiotic Stresses // Phytohormones and Abiotic Stress Tolerance in Plants. Springer Heidelberg Dordrecht London New York. 2012. P. 1-48. DOI: 10.1007/978-3-642-25829-9.

2. Hola D. Role of Brassinosteroids in the Plant Response to Drought: Do We Know Anything for Certain? // Brassinosteroids: Plant Growth and Development, Springer Nature Singapore Pte Ltd. 2019. P. 101-168. DOI: 10.1007/978-981-13-6058-9.

3. Ha Y.M., Dami Y.S., Nam K.H. Brassinosteroid Reduces ABA Accumulation Leading to the Inhibition of ABA-induced Stomatal Closure // Biochem. Biophys. Research Commun. 2018. V. 504. P. 143-148. DOI: 10.1016/j.bbrc.2018.08.146 
4. Шарипова Г.В., Веселов Д.С., Кудоярова Г.Р., Тимергалин М.Д., Wilkinson S. Влияние ингибитора рецепции этилена на рост, водный обмен и содержание абсцизовой кислоты у растений пшеницы при дефиците воды // Физиология растений. 2012. Т. 59. С. 619-626.

5. Pardossi A., Vernieri P., Tognoni F. Involvement of Abscisic Acid in Regulating Water Status in Phaseolus vulgaris L. during Chilling // Plant Physiol. 1992. V. 100. P. 1243-1250. DOI: 10.1104/pp.100.3.1243.

\title{
Effect of 24-epibrassinolide on water exchange in wheat plants under water deficit
}

\author{
A.R. Lubyanova', M.V. Bezrukova ${ }^{1}$, F.M. Shakirova ${ }^{1}$ \\ ${ }^{1}$ Institute of Biochemistry and Genetics - Subdivision of the Ufa Federal Research Centre of \\ the Russian Academy of Sciences, Russia, Ufa, 450054, October Pr., 71 lit. 1 e.
}

\section{*Email: Lubyanova555@mail.ru}

The pre-sowing treatment of wheat seeds (Triticum aestivum L.), cultivar Salavat Yulaev by $0.4 \mu \mathrm{M}$ 24-epibrassinolide (EB) influenced on water exchange of wheat seedlings under normal growth conditions and under water deficit, modulated by an osmotic - $12 \%$ polyethylene glycol (PEG). It was revealed that EB-pretreatment reduced water loss of seedlings under 12\% PEG treatment. The decrease in stress-induced water loss by the plant occurred due to regulation the processes of transpiration and accumulation of osmotically active substances.

Keywords: Triticum aestivum L., brassinosteroids, water exchange, water deficit, water content, osmotic potential of cell sap, relative water content, transpiration, 24-epibrassinolide. 